\title{
ANALISIS SOLVABILITAS PERBANKAN SYARIAH DI INDONESIA PERIODE 2001 - 2004
}

\author{
Oleh : \\ Indah Yuliana *)
}

\begin{abstract}
The birth of 'Syariah Bank' in Indonesia is really hoped by the Indonesians (especially the Moslems) who think that the interest of the bank is forbidden in Islam. However actually sharing principle in the accounting institution has been known well both in Islamic and nonIslamic countries. 'Syariah Bank' is not related with religious rituals (Islam) but it is about a sharing concept in business between the owner of the capital and the capital manager. Bank management with syariah principle can be accessed and managed by all societies and not only by the Moslems. However, it is not debatable that nowadays in Indonesia 'Syariah Bank' is developing within the Islamic societies. From this aspect, the opportunity to develop 'Syariah Bank' in Indonesia is big enough, as Indonesia is a country having the biggest Moslem followers.

'Syariah bank' as an accounting intermediary institution is hoped to be able to give a better performance than the conventional banks. The goodness and the badness of the 'Syariah Bank' can be known from its performance reflected from the accounting report. But the accounting report on the Syariah Banking sector is to provide an information related to the accounting position, performance and also accounting position, and bank activities that will be useful for the decision making.

This research aims to describe the solvability ability of Syariah Bank in Indonesia based on the banking ratio analysis technique. This is a descriptive research and the population of this research is the Syariah Bank that has been doing IPO in BEJ. The result of the research shows:

First, CAR ability from 2001 to 2004 its value is above the determined standard from BI. the CAR that is far above the standard shows that the bank has not used the capital maximally. This can be caused by the bank's doubt to distribute its capital to the risk 'assets (aktiva)'. Second, debt to equity from 2001 to 2004 gets increased. It shows that the number of debt year by year gets increased. Third, long term debt to equity from 2001 to 2003 whose values at the syariah banking industry is the smallest is 'Syariah Mandiri Bank'. While, in 2004 it is 'Indonesian Muamalat Bank'. It means 'Syariah Mandiri Bank' and 'Indonesian Muamalat Bank' are the banks which its long term debt composition is under the industrial average, so that the smaller the long term debt to equity ration, the smaller the bank 'assets (aktiva)' financed by the long term debt.
\end{abstract}

Keyword: syariah bank, ratio analysis technique, performance, solvability

\section{PENDAHULUAN}

\section{Latar Belakang}

Konsep perbankan Islam baru-baru ini ditetapkan dalam dunia perbankan dan memunculkan suatu kemunkinan kerja sama financial dan menarik perhatian international dalam konteks sebagai pendekatan alternatif untuk penggunaan sumberdaya financial bagi tujuan ekonomi secara produktif. Ruang lingkup dari perbankan Islam baik dari tingkat nasional maupun international maasih bersifat baru, dinamis dan berada dalam proses perkembangan. Gerakan perbankan Islam secara luas dapat digambarkan sebagai suatu lembaga yang terorganisasi yang bertujuan untuk 
menyebarluaskan konsep tanpa bunga (interest free bnking concept) terhadap dunia perbankan dan investasi di seluruh dunia dengan menerapkan system operasional sesuai dengan dokrin dan hukum Islam.

Tujuan dari Perbankan Islam secara umum adalah untuk mempromosikan, memajukan, dan mengembangkan aplikasi prinsip, hukum dan tradisi Islam pada setiap transaksi keuangan, perbankan dan kegiatan bisnis yang terkait lainnya. Implikasi yang tidak dapat dihindari adalah acuan kerja praktek perbankan Islam yang seringkali menjadi tidak praktis. Disisi lain, perbankan Islam seharusnya mengkonsentrasikan usahanya secara ekslusif pada kegiatan ekonomi yang dapat menguntungkan dan juga dapat diterima secara nilai-nilai Islami. Aktivitas ekonomi yang dilakukannya juga harus dapat mencakup kegiatan keuangan yang meluas seperti perdagangan komoditi, bursa, investasi bidang properti, pengembangan asst dan lainnya. Tapi sisi yang lain bank Islam juga tidak dapat terhindar dari pengaruh interaksi kelembagaan keuangan lainnya, serta dampak ekonomi seperti inflasi. Pemecahan masalah yang dapat ditempuh adalah dengan mengusahakan kinerja dan kondisi finansial bank yang sehat untuk dapat mempertahankan dan memperluas jaringan nasabah dan deposan di bank tersebut.

Sampai akhir tahun 2005 terdapat tiga bank syariah yang telah melakukan initial public offering (IPO), yaitu bank Muamalat Indonesia, bank Syariah Mandiri, dan bank Syariah Mega Indonesia. Perkembangan ini patut disambut gembira, karena sebagian umat Islam di Indonesia masih ragu untuk bermuamalah dengan perbankan konvensional yang berbasis bunga. Dengan adanya bank syariah tersebut diharapkan keragu-raguan itu akan sirna, sehingga umat Islam diharapkan dapat berperan optimal dalam industri perbankan di Indonesia.

\section{Rumusan Masalah}

Dari paparan latar belakang diatas, maka rumusan masalah dalam penelitian ini adalah "Bagaimanakah perkembangan solvabilitas perbankan syariah di Indonesia periode 2001 - 2004."

\section{Tujuan Penelitian}

Untuk mengetahui perkembangan solvabilitas perbankan syariah di Indonesia periode 2001 - 2004." 


\section{KAJIAN TEORI}

\section{Tinjauan mengenai Bank Syariah}

Di Negara-negara lain tidak dijumpai istilah bank syariah untuk menunjukkan bank yang dimaksud, karena"bank syariah" adalah istilah khas Indonesia. Di dunia Internasional, lembaga itu disebut "Islamic Bank" yang Indonesia lazim disebut bank Islam, yang sebenamya kalau diterjemahkan secara lettertijk ke dalam bahasa Indonesia seharusnya menjadi "bank Islami”.(Rahardjo,2003) Terkait dengan hal tersebut, menurut Sjahdeini, dalam sebuah diskusi tentang perbankan syariah telah muncul pemikiran untuk menyamakan istilah "bank syariah" dengan yang lazim digunakan di dunia internasional, yaitu "bank Islami" dan bukan "bank Islam". Alasan yang mendasarinya setengkapnya sebagai berikut (Sjahdeni, 2002:10):

1. Kata lslam dalam Islamic bank dan Islamic banking adalah kata sifat atau adjective. Oleh karena ttu dalam bahasa Indonesia yang tepat adalah menggunakan kata Islami, bukan Islam.

2. Adalah lebih tepat untuk menggunakan penyebutan "bank Islami" atau "perbankan islami" dari pada "bank Islam" atau "perbankan Islam", yang artinya adalah bank atau perbankan yang menerapkan atau sesuai dengan asas-asas yang islami dalam kegiatan usahanya, yaitu asas-asas syariah (hukum Islam),

3. Kalau disebut "bank islam" atau "perbankan Islam" akan menimbulkan konotasi bahwa bank tersebut adalah bank yang khusus diperuntukkan bagi orang Islam saja, sedangkan pada kenyataannya tidak demiklan. Bahkan diinginkan agar perbankan syariah dapat mendunia dan menjadi atternatif yang sangat kompetrtif atau menjadi pelengkap bagi perbankan konvensional, finance company dan investment banking.

4. Istilah "bank Islam" atau "perbankan Islam" tersebut secara harfiah dapat diartikan bahwa banknya atau perbankannya yang beragama Islam

Menurut Cyril Glasse (1988:51), bank Islam adalah sistem perbankan bebas bunga, berkisar pada penerapan sejumlah hilah-hilah klasik, yaitu:

a) Hilah murabahah dimana sebuah barang dijual, dengan perjanjian pemilik barang tersebut membelinya kembali dengan harga yang lebih tinggi.

b) Hilah masyarakat, dimana depositor menjadi seorang mitra kerja yang turut membiayai manajemen, sehingga depositor tersebut turut mendapat keuntungan usaha dan juga turut dalam menanggung kerugian. 
c) Hilah mudarabah atau "kemitraan pasif yakni pemberian seluruh beban keuangan untuk sebuah usaha dan mempercayakan sepenuhnya kepada seseorang, dan ia hanya turut dalam pembagian keuntungan.

Tentang kegiatan bank syariah ini Sjahdeini (1999:1) menjelaskan: "Seperti halnya bank konvensional, bank syariah juga berfungsi sebagai suatu lembaga intermediasi (intermediary institution), yartu mengerahkan dana dari masyarakat dan menyalurkan kembaii dana-dana tersebut kepada masyarakat yang membutuhkannya dalam bentuk fasilitas pembiayaan. Bedanya adalah bahwa bank syariah melakukan kegiatan " usahanya tidak berdasarkan bunga (interest free), tetapi berdasarkan prinsip syariah, yaitu prinsip pembagian keuntungan dan kerugian (profit and loss sharing principle) atau atau disingkat dengan PLS principle"

Lebih lanjut menurut Sjahdeini, jasa-jasa pembiayaan yang diberikan oleh bank syariah lebih beragam daripada bank konvensional, karena bukan saja pembiayaan dalam bentuk kredit (menurut bank konvensional) tetapi juga memoerikan jasa pembiayaan yang biasanya diberikan oleh lembaga pembiayaan (multi finance company) seperti leasing, hire purchase, pembelilan barang oleh nasabah bank kepada bank Islam yang bersangkutan dengan cicilan, pembelian barang oleh bank Islam kepada perusaahaan manufaktur dengan pembayaran di muka, penyertaan modal (equity participation atau venture capital, dan lain sebagainya. Untuk memberikan pelayanan kepada kaum dhuafa (ekonomi lemah/fakir miskin) Bank Syariah adakalanya melakukan pula fungsi charity (ta'awwun), dengan memberikan fasilitas pembiayaan yang disebut al qarthul hasan (benevolent loan), yaitu pinjaman uang tanpa imbalan apapun dan hanya dikembalikan dalam jumlah yang sama dengan jumlah pada waktu dipinjamkan.

\section{Dewan Syariah Nasional}

Faktor utama pendorong keberadaan bank syariah adalah keinginan pengguna jasa untuk secara kaffah menghindari larangan dan melaksanakan ketentuan syariah dalam seluruh aktivitas perbankan yang dilakukan. Oleh karena itu, salah satu kunci kebersilakan dan kesinambungan eksistensi bank syariah adalah adanya jaminan dan kepercayaan pengguna jasa bahwa bank syariah melaksanakan norma dan prinsip syariah secara benar dan istiqomah. Bank Indonesia menyadari bahwa peran monitoring serta memberikan nasihat mengenai kepatuhan kepada prinsip dan nilai syariah serta menjelaskan secara gamblang mengenai masalah halal dan halal adalah peran keulamaan yang tidak tergantikan dan tidak dapat diambil alih oleh otoritas pengaturan dan 
pengawasan bank. Sejalan dengan itu Bank Indonesia menyadari peran penting keberadaan Dewan Syariah Nasional (DSN) sebagai otoritas fatwa.

Sejak awal pengembangan perbankan syariah, Bank Indonesia telah menyadari perlunya keberadaan lembaga yang memiliki otoritas di bidang kesyariahan yang dapat mendukung terwujudnya sistem perbankan syariah yang sehat da konsisten menjalankan prinsip syariah dalam seluruh aktivitas usaha. Terciptanya jaminan kehalalan serta kesesuaian dengan prinsip syariah atas operasional bank syariah yang dikontribusikan secara nyata oleh Dewan Syariah Nasional (DSN) merupakan aspek dasar untuk memberikan keyakinan sekaligus membangun kepercayaan masyarakat atas keberadaan bank syariah kaffah.

Dengan memahami begitu strategisnya peran Dewan Syariah Nasional dalam pengembangan perbankan syariah nasional, maka untuk mengotimalkan peran Dewan Syariah Nasional dimaksud, dalam 5 tahun terakhir Bank Indonesia telah membangun kesepahaman yang dituangkan dalam memorandum kerjasama antara Bank Indonesia dan Dewan Syariah Nasional. Kesepahaman ini dimaksudkan untuk meningkatkan koordinasi antar lembaga yang terkait dengan pengaturan terhadap perbankan syariah. Secara tehnis kerjasama yang dilaksanakan adalah pertemuan koordinatif berkala yang terkait dengan perumusan produk dan transaksi perbankan syariah, disamping memberikan bantuan untuk mendukung kegiatan operasional Dewan Syariah Nasional. Diaharapkan dengan adanya pertemuan koordinatif dimaksud, maka pihak Dewan Syariah Nasional dapat memperoleh input dan pandangan mengenai aspek-aspek tehnis perbankan dan isu-isu kehati-hatian yang terkait dengan produk dan transaksi yang sedang dirumuskan fatwanya. Lebih lanjut diharapkan fatwa Dewan Syariah Nasional tentang produk dan jasa perbankan tersebut lebih implementatif karena telah memenuhi aspek tehnis dan kehati-hatian perbankan.

Dalam kaitan menciptakan sistem pengawasan bank syariah yang efektif, Bank Indonesia secara kontinyu mengembangkan regulasi dan sistem pengawasan yang sesuai dengan karakteristik bank syariah, menetapkan aturan tentang mekanisme pengeluaran setiap produk baru bank syariah yang telah difatwakan ileh DSN, serta menerapkan sistem pengawasan baik untuk penilaian aspek kehati-hatian dan kesesuaian operasional bank dengan ketentuan syariah dengan melibatkan DPS bank dan unsur pengawasan syariah lainnya. Selama tahun 2004, sejalan dengan memorandum kerjasama antara Bank Indonesia dan DSN dalam rangka meningkatkan koordinasi antar lembaga yang memiliki kewenangan pengaturan terhadap perbankan syariah, selain memberikan bantuan untuk 
mendukung kegiatan operasional DSN, Bank Indonesian juga secara aktif melakukan koordinasi khususnya dalam perumusan fatwa DSN mengenai perbankan syariah.

Hingga akhir tahun 2005 Dewan Syariah Nasional telah mengeluarkan 49 fatwa yang terkait dengan operasional perbankan syariah. Selama tahun 2005 sendiri, fatwa yang berkaitan dengan perbankan syariah yang telah dikeluarkan adalah 5 fatwa, yaitu mengenai Line Facility (No.45/DSN-MUI/II/2005), Potongan tagihan Murabahah (No.46/DSN-MUI/II/2005), Penyelesaian Piutang Murabahah Bagi Nasabah Tidak Mampu Membayar (No.47/DSN-MUI/II/2005), Penjadwalan Kembali Tagihan Murabahah (No.48/DSN-MUI/II/2005) dan Konversi Akad Murabahah (No.49/DSNMUI/II/2005). Selain aktivitas penyusunan fatwa produk dan jasa perbankan syariah, DSN juga secara aktif memberikan konsultasi kepada perbankan syariah terkait dengan pengembangan produk baru dan keraguan dalam penerapan fatwa dalam operasional bank, hasil pertemuan konsultatif tersebut adalah opini kesyariahan. (Laporan perkembangan Perbankan Syariah Tahun 2005)

Pada tahun 2005, DSN juga melakukan inisiatif untuk merekomendasikan kepada pemerintah (Departemen Agama RI) untuk mempertimbangkan penggunaan bank syariah sebagai bank mengelola dana setoran biaya perjalanan haji.

\section{Peraturan Bank Syariah di Indonesia}

Sungguhpun dalam kegiatan operasioanal antara bank syariah dan bank konvesional terdapat perbedaan, namun demikian bank syariah tetap mengikuti peraturan-peraturan dan persyaratan perbankan yang berlaku pada umumnya, antara lain :

a. Ketentuan perizinan dalam pengembangan usaha, seperti pembukaan cabang dan kegiatan devisa

b. Kewajiban pelaporan ke Bank Indonesia

c. Pengawasan Intern

d. Pengawasan atas prestasi, permodalan, manajemen,rentabilitas, likuiditas dan faktor lainnya

e. Pengenaan sanksi atas pelanggaran.

Disamping ketentuan-ketentuan diatas Bank Syariah di Indonesia juga dibatasi oleh pengawasan yang dilakukan oleh Dewan Pengawas Syariah 


\section{Ruang lingkup pengawasan Bank Indonesia (BI) dan Dewan Syariah nasional terhadap}

Aspek Administratif, Keuangan, dan Syariah Compliance Bank Islam

Dalam undang-undang perbankan dinyatakan dengan tegas, bahwa pembinaan dan pengawasan bank dilakukan oleh Bank Indonesia (BI). Berkaitan dengan perbankan Islam, tugas BI adalah membuat aturan-aturan strategis dan tehnis yang berupa normanorma hukum yang diberlakukan terhadap seluruh stake holder untuk mendukung perkembangan bank Islam (Indonesia "Undang-undang RI No. 10 tahun 1998 tentang perbankan)

\section{a. Aspek administratif}

Bentuk pengawasan administratif oleh BI terhadap sektor perbankan Islam antara lain tentang perubahan kegiatan usaha dan pembukaan Kantor Cabang Syariah dan pendirian bank berdasarkan Prinsip Syariah. Dalam peraturan ini disebutkan antara lain, bahwa bagi bank konvensional yang ingin mengubah usahanya menjadi Bank Islam atau membuka cabang Syariah atau mendirikan Bank Syariah harus mendapat izin dari Gubernur BI. Saat ini semakin banyak bank konvensional yang mengubah kegiatan usahanya atau membuka kegiatan cabag syariah. Kondisi ini menunjukkan bahwa keberadaan bank Islam sebagai bank yang menggunakan sistem baru dikenal di Indonesia semakin kokoh. Sistem Syariah sudah dapat diterima bahkan menjadi salah satu pilihan terbaik dalam mengembangkan usaha perbankan. Kondisi ini tidak saja patut disyukuri, namun BI seharusnya semakin cermat dalam mengawasi bank konvensional yang membuka cabang Syariah atau mengubah kegiatan usahanya menjadi bank Islam. Dikhawatirkan tujuan mereka hanyalah mencari keuntungan sesaat tanpa memahami secara penuh apa makna dari bank Islam itu sendiri. Selain itu perlu diperhatikan karier SDM yang bekerja di induk perusahaan yang konvensional dengan anak perusahaan yang syariah. Bila jabatan tertinggi mereka di anak perusahaan adlaha sebagai Kepala Devisi, karier mereka sebagai karyawan hanya selesai hingga di situ. Bila mereka ingin menaiki jenjang karier yang lebih tinggi mereka harus kembali ke induk perusahaan yang notabene adalah bank konvensional. Jadi di sini tidak nampak kesungguhan SDM dalam melaksanakan syariah Islam secara kaffah. Selain itu kemampuan mereka dalam bidang perbankan syariah akan tidak termanfaatkan lagi. Oleh karena itu bank konvensional yang membuka cabang bank syariah di bawah koordinasi Unit Usaha Syariah (UUS) dikantor pusat, seharusnya membuat perencanaan SDM syariahnya Jangan sampai 
terjadi mereka yang sudah mapan di UUS ditarik kembali ke induknya yang masih konvensional.

\section{b. Aspek Keuangan}

Dalam aspek keuangan BI, memiliki kewenangan untuk menetapkan batas maksimum pembiayaan berdasarkan Prinsip Syariah yang harus dipatuhi oleh bank Islam. Bank Islam dalam hal ini berkewajiban menyampaikan kepada BI, segala keterangan, dan penjelasan mengenai usahanya menurut tata cara yang ditetapkan BI, dan menyampaikan neraca dan perhitungan rugi laba tahunan serta penjelasannya, serta laporan berkala lainnya kepada BI, dalam waktu dan bentuk yang ditetapkan BI. Pelanggaran terhadap kewajiban tersebut diancam dengan pidana. Hal ini perlu diperhatikan dalam pembuatan laporan keuangan adalah dengan menggunakan Standar Akuntansi Keuangan Syariah (PSAK No. 59)

c. Aspek Pengawasan Syariah.

Dari segi syariah compliance, sampai saat ini belum ada satu peraturan yang mengatur kewenangan dan tugas BI. Memang, Undang-undang Perbankan secara umum mengatur norma maupun code of conduct bank, yang mungkin dapat dipahami sebagai implementasi Prinsip Syariah, yaitu antara lain kewajiban Bank Islam untuk menmpuh cara-cara yang tidak merugikan bank dan kepentingan nasabah dalam memberikan pembiayaan dalam prinsip syariah. Juga kewajiban Bank Islamuntuk mempunyai keyakinan dan melakukan analisis yang mendalam berdasarkan itikad baik, kemampuan dan kesanggupan nasabah debitur dalam hal pembiayaan berdasarkan prinsip syariah. Ketentuan tersebut tidak memberikan arahan seberapa jauh BI dapat menilai dan bertindak dalam menentukan apakah produk jasa ataupun praktik Bank Islam telah sesuai dengan prinsip Syariah. Hingga saat ini kewenangan tersebut diberikan kepada Dewan Pengawas Syariah yang ada di dalam bank-bank tersebut. Kewenangan DPS ini akan berfungsi baik bila DPS tetap mempertahankan independensinya. Kewenangan untuk melakukan syariah compliance dapat diserahkan ke DSN karena dalam hal ini DSN merupakan satu-satunya badan yang mempunyai kewenangan mengeluarkan fatwa atas jenis kegiatan, produk, dan jasa keuangan syariah, serta mengawasi penerapan fatwa dimaksud oleh lembaga lembaga keuangan syariah di Indonesia.

Pengawasan bank oleh BI dalam prakteknya diarahkan pada penyempurnaan pengaturan dan metode pengawasan melalui program-program, yaitu: 
a. Program risk based supervision yaitu pengawasan berdasarkan risiko. Pendekatan ini dimaksudkan untuk mengetahui sejauhmana bank dapat mengendalikan risiko kerugian dimasa yang akan datang atas posisi bank pada saat ini sehingga otoritas pengawas mampu melakukan tindakan pembinaan secara labih dini. Di sisi lain bank juga diminta untuk menerapkan risk management dalam kegia tan operasionalnya.

b. Program on site supervisory presence (OPS) yang merupakan bagian dari kegiatan pengawasan dengan cara menempatkan pengawas pada bank yang dilakukan secara (day to day supervision). BI melakukan OPS dalam rangka pengawasan terhadap bank yang dikategorikan dalam pengawasan intensif dan atau pengawasan khusus.

c. Pengawasan Intensif dan Pengawasan Khusus, BI melakukan pengawasan intensif (intensive supervision) pada bank yang dinilai memiliki potensi kesulitan yang dapat membahayakan kelangsungan usahanya. Selanjutnya bila suatu bank dinilai mengalami kesulitan yang membahayakan kelangsungan usahanya maka bank tersebut ditempatkan dalam pengawasan khusus (special surveillance), (Booklet Perbankan Indonesia, 2002:9-10).

Bank Indonesia sebagai bank otoritas yang meiakukan tugas pengaruran dan pengawasan bank berhak menetapkan peraturan, memberikan dan mencabut izin atas kelembagaan dan kegiatan usaha tertentu bank, melaksanakan pengawasan bank serta mengenakan sanksi terhadap bank. Adapun tujuan dari dilaksanakan pengaturan dan pengawasan bank sebagaimana yang disebutkan dalam booklet perbankan Indonesia adalah untuk mengoptimalkan fungsi perbankan Indonesia sebagai:

a. Lembaga kepercayaan masyarakat dalam kaitannya sebagai lembaga penghimpun dan penyalur dana.

b. Pelaksana kebijakan moneter.

c. Lembaga yang ikut berperan dalam membantu pertumbuhan ekonomi serta pemerataan.

Agar tercipta perbankan yang sehat, sistem perbankan secara meyeluruh maupun individual dan mampu memelihara kepentingan masyarakat dengan baik, berkembang secara wajar dan bermanfaat bagi perekonomian nasional. Untuk mencapai tujuan tersebut pendekatan yang dilakukan adalah dengan menerapkan:

1. Kebijakan memberikan keleluasaan berusaha (deregulasi)

2. Kebijakan prmsip kehati-hatian (prudential banking) dan

3. Pengawasan bank yang mendorong bank untuk melaksanakan secara konsisten ketentuan intern yang dibuat sendiri (self regulatory banking) dalam melaksanakan 
kegiatan operasionalnya dengan tetap mengacu pada prinsip kehati-hatian, (Booklet Perbankan Indonesia, 2002:12).

\section{Laporan Keuangan Bank Syariah}

Laporan keuangan merupakan informasi yang diharapkan mampu memberikan bantuan kepada pengguna untuk membuat kcputusaii ekonomi yang bersifat financial, (Weston \& Copeland, 1995:25). Pendapat lain menyebutkan bahwa laporan keuangan adalah hasil akhir dan proses pencatatan yang merupakan suatu rangkaian dari transaksi keuangan yang terjadi selama tahun buku yang bersangkutan, (Baridwan, 1992:17).Jadi dapat disimpulkan bahwa laporan keuangan adalah hasil akhir dari proses pencatatan transaksi keuangan yang terjadi selama tahun buku yang bersangkutan yang diharapkan dapat memberikan bantuan kepada pengguna dalam membuat keputusan ekonomi yang bersifat finansial.

Tujuan laporan keuangan selain memberikan informasi yang akurat, juga untuk melihat secara jelas perubahan posisi keuangan dari waktu ke waktu untuk kepentingan analisis kondisi keuangan dan pengambilan keputusan baik bagi, manajemen, pemegang saham maupun pihak lain yang berkepentingan dengan bank. Oleh karena itu, laporan keuangan wajib di umumkan kepada publik paling lambat empat bulan setelah berakhirnya tahun laporan.

Adapun tujuan pelaporan keuangan dalam konsep Islam adalah:

1. Penentuan pendapatan dan penilaian kekayaan (assets) sebagai dasar penunaian pembayaran zakat.

2. Untuk membuktikan telah terjadi transaksi (muamalah) maka harus dilakukan pencatatan.

3. Mencegah terjadinya manipulasi transaksi atau hasil dari transaksi bisnis.

4. Memberikan informasi kepada pemakai yang bermanfaat dalam pembuatan keputusan, (Zulkifli \& Sulastiningsih, 1998:175).

Perangkat laporan keuangan lengkap yang harus diterbitkan oleh bank-bank Islam adalah:

1. Laporan posisi keuangan (neraca)

2. Laporan laba-rugi

3. Laporan arus kas

4. Laporan perubahan modal pemilik dan laporan laba ditahan

5. Laporan perubahan investasi terbatas 
6. Laporan sumber dan penggunaan dana zakat dan dana sumbangan (apabila bank bertanggungjawab atas pengumpulan dan pembagian zakat)

7. Laporan sumber dan penggunaan dana qard

8. Catatan-catatan laporan keuangan

9. Pernyataan, laporan dan data lain yang membantu dalam menyediakan informasi yang diperlukan oleh para pemakai laporan keuangan sebagaimana ditentukan di dalam statement of objective, (Arifin, 2003:72).

Pembuatan masing-masing laporan keuangan memiliki tujuan tersendiri. Secara umum tujuan pembuatan laporan keuangan adalah (Kasmir, 2004: 240)

1. Memberikan informasi keuangan tentang jumlah aktiva dan jenis aktiva yang dimiliki

2. Memberikan informasi keuangan tentang jumlah kewajiban dan jenis kewajiban baik jangka pendek maupun jangka panjang

3. Memberikan informasi keuangan tentang jumlah modaldan jenis modal bank pada waktu tertentu

4. Memberikan informasi tentang hasil usaha yang tercermin dari jumlah pendapatan yang diperoleh dari sumber-sumber pendapatan bank tersebut.

5. Memberikan informasi keuangan tentang jumlah biaya-biaya yang dikeluarkan berikut jenis biaya yang dikeluarkan pada periode tertentu

6. Memberikan informasi tentang perubahan-perubahan yang terjadi dalam aktiva, kewajiban dan modal suatu bank

7. Memberikan informasi tentang kinerja manajemen dalam suatu periode

Laporan keuangan bertujuan untuk menyediakan informasi yang bermanfaat bagi pihak-pihak yang berkepentingan dalam pengambilan keputusan ekonomi yang rasional, seperti:

1. Shahibul maal/ pemilik dana

2. Pihak-pihak yang memanfaatkan dan menerima penyaluran dana

3. Pembayar zakat, infaq dan shadaqah

4. Pemegang saham

5. Otoritas pengawasan

6. Bank Indonesia

7. Pemerintah

8. Lembaga penjamin simpanan

9. Masyarakat (Pedoman Akuntansi Perbankan Syariah Indonesia, 2003) 
Informasi bermanfaat yang disajikan dalam laporan keuangan, antara lain, meliputi informasi :

1. Untuk pengambilan keputusan investasi dan pembiayaan

2. Untuk menilai prospek arus kas baik penerimaan maupun pengeluaran kas di masa datang

3. mengenai sumber daya ekonomis baik bank, kewajiban bank untuk mengalihkan sumber daya tersebut kepada entitas lain atau pemilik saham serta kemungkinan terjaadinya transaksi dan peristiwa yang dapat mempengaruhi perubahan sumber daya tersebut.

4. Mengenai kepatuhan bank terhadap prinsip syariah termasuk pendapatan dan pengeluaran yang tidak sesuai dengan prinsip syariah dan bagaimana pendapatan tersebut diperoleh serta penggunaannya.

5. Untuk membantu mengevaluasi pemenuhan tanggung jawab bank terhadap aman ah dalam mengamankan dana, mengivestasikannya pada tingkat keuntungan yang layak dan informasi mengenai tingkat keuntungan investasi terikat.

6. Mengenai pemenuhan fungsi sosial bank, termasuk pengelolaan dan penyaluran zakat

\section{Analisis Laporan Keuangan Bank}

Analisis laporan keuangan merupakan hubungan antara suatu angka dalam laporan keuangan dengan angka lain yang mempunyai makna atau dapat menjelaskan ke arah perubahan (Soemarsono, 1992). Analisis rasio keuangan yang digunakan untuk melihat kemampuan perbankan syariah dalam memenuhi kewajiban jangka panjangnya adalah dengan menghitung rasio Solvabilitas.

Rasio solvabilitas adalah analisis yang digunakan untuk mengukur kemampuan bank dalam memenuhi kewajiban jangka panjangnya. Di samping itu, rasio ini juga digunakan untuk mengetahui perbandingan antara volume dana yang diperoleh dari berbagai hutang serta sumber-sumber lain di luar modal bank sendiri dengan volume penanaman dana tersebut pada berbagai aktiva yang dimiliki bank. Dalam analisis solvabilitas digunakan rasio antara lain capital adequacy ratio, debt to equity ratio, dan long term debt to assets ratio (Dandawijaya, 2000:122)

1) Capital Adequacy Ratio

Pada tahun 1980-an terdapat ketimpangan pada struktur pada perbankan internasional yang diindikasikan dengan adanya persaingan "unfair" antara bank-bank 
Jepang dan bank-bank Amerika dan Eropa di pasar keuangan internasional. Akibat dari persaingan tersebut maka situasi pinjaman internasional menjadi terganggu dan akhirnya likuiditas internsional juga terganggu. Berdasarkan alasan tersebut maka Bank for International Settlements (B.I.S) menetapkan ketentuan dan perhitungan Capital Adequacy Ratio (CAR) yang harus diikuti oleh seluruh bank yang ada di dunia. Ketetapan B.I.S tersebut adalah ketentuan mengenai rasio minimum permodalan terhadap aktiva yang mengandung resiko. Menurut Dandawijaya (2000: 122). Capital Adequacy Ratio (CAR) adalah rasio kinerja bank untuk mengukur keeukupan modal yang dimiliki bank untuk menunjang aktiva yang mengandung atau menghasilkan resiko. Di Indonesia sendiri standart CAR mengalami banyak perubahan yaitu:

1. Sejak akhir Maret 1992 CAR minimal $=5 \%$

2. Sejak akhir Maret 1993 CAR minimal $=7 \%$

3. Sejak akhir Desember 1993 CAR minimal $=8 \%$ Perhitungan CAR

Perhitungan penyediaan modal minimum atau keeukupan modal bank didasarkan pada rasio atau perbandingan antara modal yang dimiliki bank dan jumlah Aktiva Tertimbang . Menurut Resiko (ATMR). Modal disini merupakan modal inti ditambah dengan modal pelengkap. Yang termasuk dalam modal inti antara lain modal disetor, agio saham, cadangan dan laba ditahan. Yang termasuk modal pelengkap adalah cadangan revaluasi aktiva tetap, cadangan penghapusan aktiva yang diklasiflkasikan, modal kuasi dan pinjaman subordinasi. Sedangkan ATMR merupakan penjumlahan dari ATMR neraca dan ATMR administratif. Setelah ATMR (Aktiva Tertimbang Menurut Resiko) dan Modal Bank (Modal Inti dan Pelengkap) sudah diketahui, maka Capital Adequacy Ratio dapat dihitung dengan menggunakan rumus:

Capital adequacy ratio = $\frac{\text { Modal bank }}{\text { Aktiva tertimbang menurut resiko }}$

Hasil perhitungan diatas, kemudian dibandingkan dengan kewajiban penyediaan modal minimum (yaitu sebesar 8\%). Berdasarkan hasil perbandingan tersebut, dapatlah diketahui apakah bank tersebat telah memenuhi ketentuan CAR atau tidak. Jika hasil perbandingan sama dengan $100 \%$ atau lebih maka bank tersebut telah memenuhi ketentuan CAR dan bila kurang dari 100\% maka bank tersebut belum memenuhi ketentuan CAR. (Dandawijaya, 2000:49)

2) Debt to Equity Ratio

Debt to Equity Ratio adalah rasio yang digunakan untuk mengukur kemampuan bank dalam menutup sebagian atau seluruh utang-utangnya, baik jangka panjang maupun 
jangka pendek, dengan dana yang berasal dari modal bank sendiri. Semakin kecil Debt to Equity Ratio maka semakin besar pula kemampuan bank untuk menutup hutanghutangnya dengan menggunakan modal sendiri.

Debt to equity ratio $=\frac{\text { Jumlah utang }}{\text { Jumlah modal sendiri }} \times 100 \%$

3) Long Term Debt to Assets Ratio

Rasio ini digunakan untuk mengukur seberapa jauh nilai seluruh aktiva bank dibiayai atau dananya diperoleh dari sumber-sumber utang jangka panjang (Dandawijaya, 2000:123). Dalam bisnis perbankan, utang jangka panjang biasanya diperoleh dari simpanan masyarakat dengan jatuh tempo diatas satu tahun, pinjaman bank lain dalam rangka kerjasama, pinjaman luar negeri, pinjaman dari Bank Indonesia serta pinjaman dari para pemegang saham. Semakin besar rasio ini maka semakin besar utang jangka panjang bank yang dibiayai oleh aktivanya. Rasio ini dirumuskan sebagai berikut:

Long term debt to equity ratio = - Utang jangka panjang

Total aktiva

\section{METODE PENELITIAN}

\section{Jenis Penelitian}

Penelitian ini menggunakan jenis penelitian deskriptif, yaitu suatu penelitian yang bertujuan untuk memberikan gambaran atau lukisan secara sistematis, faktual dan akurat mengenai fenomena atau hubungan antara fenomena yang diselidiki. Metode deskriptif ini menekankan gambaran obyek yang diselidiki dalam keadaan sekarang (Imam dan Tabroni, 2001:137). Penelitian deskriptif pada dasarnya ditujukan untuk membuat deskripsi, gambaran atau lukisan secara sistematis, faktual mengenai fakta-fakta, sifatsifat serta hubungan antar fenomena yang diselidiki. Selain itu penelitian deskriptif juga menghimpun data tetapi tidak melakukan pengujian hipotesa. Penelitian ini dipusatkan pada masalah tertentu dan dalam ruang lingkup tertentu sehingga dapat digolongkan dalam tipe pendekatan studi kasus (case studies). Sebagaimana diungkapkan bahwa studi kasus merupakan tipe pendekatan dalam penelitian yang penelaahannya kepada satu kasus dilakukan secara intensif, mendalam, mendetail dan komprehensif. Studi kasus bisa dilakukan terhadap individu juga bisa dilakukan terhadap kelompok (Faisal, 2001:22). Dalam penelitian kasus ini tidak sampai mempermasalahklan hubungan antara variabelvariabel yang ada dan juga tidak dimaksudkan untuk menarik suatu generalisasi yang menjelaskan variabel yang menyebabkan suatu kenyataan sosial. 


\section{Konsep dan Variabel Penelitian}

Konsep yang dipakai dalam penelitian ini adalah rasio kaeuangan perbankan yaitu:rasio solvabilitas.

Rasio Solvabilitas:

Adalah analisis yang digunakan untuk mengukur kemampuan bank dalam memenuhi kewajiban-kewajiban jangka panjangnya

1) Capital Adequacy Ratio adalah rasio kinerja bank untuk mengukur kecukupan modal yang dimiliki bank untuk menunjang aktiva yang mengandung atau menghasilkan resiko selama 1 tahun yang dinyatakan dalam persen.

2) Debt to Equity Ratio adalah rasio yang digubakan untuk mengukur kemampuan bank dalam menutup sebagian atau seluruh utang-utangnya, baik jangka panjang maupun jangka pendek, dengan dana yang berasal dari modal bank sendiri selama 1 tahun yang dinyatakan dalam persen.

3) Long Term Debt to Assets Ratio Rasio ini digunakan untuk mengukur seberapa jauh nilai seluruh aktiva bank dibiayai atau dananya diperoleh dari sumber-samber utang jangka panjang selama 1 tahun yang dinyatakan dalam persen.

\section{Teknik Pengumpulan Data}

Teknik pengumpulan data merupakan suatu cara yang digunakan untuk mengumpulkan data. Data yang terkumpul akan digunakan sebagai bahan analisis. Oleh karena itu, pengumpulan data harus dilakukan secar sistematis, terarah dan sesuai dengan masalah penelitian.

Teknik pengumpulan data dalam penelitian ini menggunakan metode dokumentasi yang merupakan suatu teknik pengumpulan data dengan jalan mengambil data yang ada pada bank syariah berkaitan dengan masalah yang hendak diteliti. Misalnya berupa arsip laporan keuangan bank berupa neraca dan laporan rugi laba, sejarah perusahaan, struktur organisasi, dokumen-dokumen dan penelitian terdahulu yang berkaitan dengan perbankan.

\section{Instrumen Penelitian}

Instrumen penelitian merupakan alat atau fasilitas yang digunakan peneliti dalam mengumpulkan data agar pekerjaannya lebih mudah dan hasilnya lebih baik, cermat, lengkap dan sistematis sehingga mudah diolah. Instrumen penelitian ini digunakan untuk memperoleh data yang valid dan representatif. Dalam penelitian ini instrumen 
penelitian yang digunakan adalah pedoman dokumentasi, yaitu menggunakan instrumen yang berupa alat dokumentasi dalam memperoleh data yang meliputi dokumen bank syariah berupa laporan keuangan

\section{Metode Analisis}

Analisis data adalah proses penyederhanaan data ke dalam bentuk yang lebih mudah dibaca dan diinterpretasikan. Analisis data merupakan bagian yang amat penting dalam penelitian karena dengan melakukan analisis data maka data tersebut dapat berarti dan bermakna untuk memecahkan masalah penelitian.

Analisis data dalam penelitian ini menggunakan pendekatan kuantitatif yaitu mengklasifikasikan, menghitung, membandingkan, menganalisis data yang ada, menggunakan bantuan rasio-rasio atau perimbangan antara suatu jumlah tertentu dalam satuan-satuan hitungan. Adapun data yang berwujud angka-angka hasil hitungan dianalisis dengan menggunakan analisis time series.

Pada prinsipnya ada dua cara yang dapat dilakukan dalam membandingkan rasio finansial perusahaan, yaitu cross-sectional approach dan time series analisys. Yang dimaksud dengan cross sectional approach adalah suatu cara mengevaluasi dengan jalan membandingkan ratio-ratio antara perusahaan yang satu dengan perusahaan yang lainnya yang sejenis pada saat yang bersamaan. Sedangkan time series analisys dilakukandengan jalan membandingkan ratio-ratio financial perusahaan dari satu period eke periode lainnya. (Syamsudin, 2001:39). Tehnik analisis rasio yang digunakan adlah rasio keuangan perbankan yang meliputi:

Solvabilitas

1. Capital adequacy ratio (CAR)

Capital adequacy ratio $=\frac{\text { Modal bank }}{\text { Aktiva tertimbang menurut resiko }}$

2. Debt to equity ratio

Debt to equity ratio $=\frac{\text { Jumlah utang }}{\text { Jumlah modal sendiri }} \times 100 \%$

3. Long term debt to equity ratio

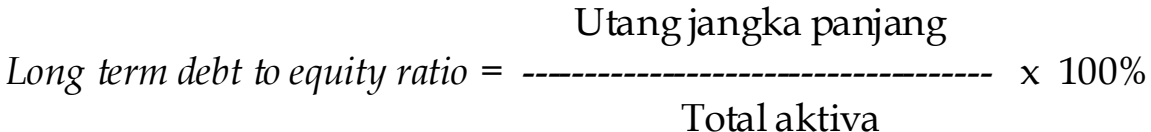




\section{HASIL PENELITIAN}

\section{Deskripsi Data dan Analisis Data}

\section{Aspek Solvabilitas}

\section{a. Capital Adequacy ratio}

Capital adequacy ratio rata-rata industri perbankan syariah pada tahun 2001 cukup tinggi yaitu sebesar 27,84\%. Pada tahun 2002 mengalami penurunan sebesar 8,03\% sehingga CAR rata-rata industri menjadi 19,81\%. Tahun 2003 mengalami penurunan kembali sebesar 5,27\% sehingga CAR menjadi 14,54\%. Namun pada tahun 2004 CAR rata-rata industri meningkat menjadi $14,72 \%$.

Tabel 1. CAR Rata-Rata Industri

Tahun 2001 s.d 2004

(dalam jutaan Rp)

\begin{tabular}{|l|r|r|r|r|}
\hline \multicolumn{1}{|c|}{ Keterangan } & Tahun 2001 & Tahun 2002 & Tahun 2003 & \multicolumn{1}{c|}{$\begin{array}{c}\text { Tahun } \\
2004\end{array}$} \\
\hline (CAR) Bank Mandiri Syariah & 63.18 & 39.29 & 20.87 & 10.57 \\
\hline $\begin{array}{l}\text { (CAR) Bank Muamalat } \\
\text { Indonesia }\end{array}$ & 9.26 & 10.26 & 13.16 & 12.33 \\
\hline $\begin{array}{l}\text { (CAR) Bank Syariah Mega } \\
\text { Indonesia }\end{array}$ & 11.07 & 9.89 & 9.58 & 21.26 \\
\hline Total (CAR) & 83.51 & 59.44 & 43.61 & 44.16 \\
\hline Rata-rata (CAR) & $\mathbf{2 7 . 8 3 6 6 6 6 6 7}$ & $\mathbf{1 9 . 8 1 3 3 3 3 3 3}$ & $\mathbf{1 4 . 5 3 6 6 6 6 6 7}$ & $\mathbf{1 4 . 7 2}$ \\
\hline
\end{tabular}

Sumber : data diolah

Rasio kecukupan modal yang dimiliki untuk menunjang aktiva yang mengandung atau menghasilkan resiko Bank Syariah Mandiri pada tahun 2001 sebesar 63,81\%. Sedangkan pada tahun 2002 sampai 2004 mengalami penurunan sehingga CAR menjadi 39,29\% pada tahun 2002, dan 20,87\% pada tahun 2003. Pada tahun 2004 mengalami penurunan kembali sehingga CAR menjadi 10,57\%.

Capital adequacy ratio Bank Muamalat Indonesia pada tahun 2001 sebesar 9,26\%, sedangkan pada tahun 2002 meningkat 1\% sehingga menjadi 10,26\%. Pada tahun 2003 meningkat menjdi $13,16 \%$ atau naik 2,9\%. Tahun 2004 CAR mengalami penurunan sebesar 0,83\%.Besarnya CAR Bank Syariah Mega Indonesia pada tahun 2001 adalah 11,07\%. Sedangkan pada tahun 2002 dan tahun 2003 mengalami penurunan secara berturut-turut yaitu sebesar $1,18 \%$ pada tahun 2002 dan $0,31 \%$ pada tahun 2003 . Pada tahun 2004 mengalami peningkatan sebesar 11,68\%, sehingga CAR menjadi 21,26\%. 


\section{b. Debt to Equity}

Debt to equity adalah rasio yang digunakan untuk mengukur keampuan bank dalam menutup sebagian atau seluruh hutangnya, baik jangka pendek maupun jangka panjang, dengan dana yang berasal dari modal sendiri. Semakin kecil debt to equity maka semakin besar pula kemampuan bank untuk menutup hutang-hutangnya dengan modal sendiri. Debt to equity rata-rata industri perbankan syariah mulai tahun 2001 sampai 2004 mengalami peningkatan secara terus menerus. Pada tahun 2001 sebesar 444,77\%. Tahun 2002 sebesar 612,44\% dan tahun 2003 sebesar 697,34\%. Sedangkan tahun 2004 sebesar $796,64 \%$.

Tabel 2. Debt to Equity Rata-Rata Industri

Tahun 2001 s.d 2004

(dalam jutaan Rp)

\begin{tabular}{|l|r|r|r|c|}
\hline \multicolumn{1}{|c|}{ Keterangan } & \multicolumn{1}{c|}{$\begin{array}{c}\text { Tahun } \\
\text { 2001 }\end{array}$} & \multicolumn{1}{c|}{\begin{tabular}{c} 
Tahun \\
\multicolumn{1}{|c|}{2002}
\end{tabular}} & \multicolumn{1}{c|}{$\begin{array}{c}\text { Tahun } \\
2003\end{array}$} & \multicolumn{1}{c|}{$\begin{array}{c}\text { Tahun } \\
2004\end{array}$} \\
\hline $\begin{array}{l}\text { Debt To Equity (\%) Bank } \\
\text { Syariah Mandiri }\end{array}$ & 133.56 & 278.58 & 662.29 & 560.21 \\
\hline $\begin{array}{l}\text { Debt To Equity (\%) Bank } \\
\text { Muamalat Indonesia }\end{array}$ & 876.1 & 1174.34 & 972.97 & 1491.35 \\
\hline $\begin{array}{l}\text { Debt To Equity (\%) Bank } \\
\text { Syariah Mega Ind }\end{array}$ & 324.66 & 384.4 & 456.76 & 338.36 \\
\hline Total Debt To Equity (\%) & $1,334.32$ & 1837.32 & 2092.02 & 2389.92 \\
\hline Rata-rata Debt To Equity (\%) & $\mathbf{4 4 4 . 7 7}$ & $\mathbf{6 1 2 . 4 4}$ & $\mathbf{6 9 7 . 3 4}$ & $\mathbf{7 9 6 . 6 4}$ \\
\hline
\end{tabular}

Sumber : data diolah

Mulai tahun 2001 sampai dengan 2004 debt to equity Bank Syariah Mandiri terus meningkat. Pada tahun 2001 debt to equity sebesar 133,56\%, sedangkan pada tahun 2002 meningkat sebesar 145,02\%, sehingga debt to equity sebesar 278,58\%. Tahun 2003 mengalami peningkatan lagi sebesar 383,71\%. Pada tahun 2004 debt to equity mengalami penurunan sebesar $102,08 \%$.

Besarnya debt to equity yang dimiliki Bank Muamalat Indonesia merupakan yang terbesar di industri perbankan syariah mulai tahun 2001 sampai dengan 2004. Dimana pada tahun 2001, debt equitynya mencapai 876,1\%. Pada tahun 2002 meningkat menjadi 1174,3\%, sedangkat pada tahun 2003 mengalami penurunan $201.37 \%$. Tahun 2004 debt to equity mengalami peningkatan kembali sebesar 518,38\%. Bank Syariah Mega Indonesia memiliki debt to equity terkecil dibandingkan dengan Bank Syariah Mandiri dan Bank Muamalat Indonesia. Terlihat bahwa pada tahun 2001 debt to equity sebesar 324,66\%. Pada tahun 2003 debt to equity mengalami peningkatan 59,74\%, sehingga jumlahnya mencapai $384,4 \%$. Sedangkan pada tahun 2004 debt to equity mengalami penurunan sebesar $118,4 \%$. 


\section{c. Long Term Debt to Equity Ratio}

Long term debt to equity ratio rata-rata industri pada tahun 2001 sebesar 62,9\%. Sedangkan pada tahun 2002 mengalami kenaikan sebesar 2,94\%. Pada tahun 2003 dan tahun 2004 mengalami penurunan sebesar 1,67\% dan 5,04\% pada tahun 2004.

Tabe1 3. Long Term Debt to Equity Rata-Rata Industri Tahun 2001 s.d 2004

(dalam jutaan Rp)

\begin{tabular}{|l|r|r|r|r|}
\hline \multicolumn{1}{|c|}{ Keterangan } & Tahun 2001 & Tahun 2002 & Tahun 2003 & Tahun 2004 \\
\hline $\begin{array}{l}\text { Long Term Debt To Equity } \\
\text { Ratio BSM }\end{array}$ & 29.86 & 42.61 & 55.7 & 54.84 \\
\hline $\begin{array}{l}\text { Long Term Debt To Equity } \\
\text { Ratio BMI }\end{array}$ & 70.55 & 66.35 & 53.58 & 43.45 \\
\hline $\begin{array}{l}\text { Long Term Debt To Equity } \\
\text { Ratio SMI }\end{array}$ & 88.24 & 88.55 & 83.22 & 79.11 \\
\hline $\begin{array}{l}\text { Total Long Term Debt To } \\
\text { Equity Ratio }\end{array}$ & 188.65 & 197.51 & 192.5 & 177.4 \\
\hline $\begin{array}{l}\text { Rata-rata Long Term Debt To } \\
\text { Equity Ratio }\end{array}$ & $\mathbf{6 2 . 8 8 3 3 3 3 3 3}$ & $\mathbf{6 5 . 8 3 6 6 6 6 6 7}$ & $\mathbf{6 4 . 1 6 6 6 6 6 6 7}$ & $\mathbf{5 9 . 1 3 3 3 3 3 3 3}$ \\
\hline
\end{tabular}

Sumber : data diolah

Besarnya long term debt to equity ratio Bank Syariah Mandiri pada tahun 2001 sebesar 29,86\%. Sedangkan pada tahun 2002 mengalami peningkatan sebesar 12,75\%. Pada tahun 2003 meningkat 13,09\%, dan untuk tahun 2004 mengalami penurunan sebesar 0,86\%.

Mulai tahun 2001 sampai dengan 2004 long term debt to equity ratio Bank Muamalat Indonesia mengalami penurunan. Diawali long term debt to equity ratio pada tahun 2001sebesar 70,55\%. Sedangkan pada tahun 2002 mengalami penurunan sebesar 4,2\%. Tahun 2003 dan tahun 2004 kembali mengalami penurunan sebesar 12,77\%, disusul tahun 2004 sebesar $10,13 \%$.

Long term debt to equity Bank Syariah Mega Indonesia pada tahun 2001 sebesar 88,24\%. Pada tahun 2002 sebesar 88,55\%. Tahun 2003 dan 2004 mengalami penurunan sebesar $5.33 \%$ dan $4,11 \%$ pada tahun 2004 .

\section{PEMBAHASAN}

\section{Rasio Solvabilitas}

Bank Indonesia menetapkan bahwa rasio capital adequacy ratio (CAR) minimum atau yang wajib bagi setiap bank adalah $8 \%$. Rata-rata CAR industri perbankan syariah mulai dari tahun 2001 sampai dengan tahun 2004 masih menunjukkan angka yang cukup besar (diatas 8\%). Besarnya CAR yang jauh diatas standar menunjukkan bank belum 
menggunakan modalnya secara optimal. Hal ini mengindikasikan bahwa bank syariah masih ragu untuk menyalurkan dananya pada aktiva yang beresiko. Namun dari tahun 2001 sampai dengan tahun 2004 rata-rata rasio CAR perbankan syariah mengalami penurunan, hal ini menunjukkan bahwa bank mulai menggunakan dananya untuk membiayai aktiva-aktiva yang beresiko. Pada tahun 2001 sampai dengan tahun 2003 rasio CAR terbesar dicapai oleh bank Mandiri Syariah, yaitu 63,18\% dan tahun 2004 oleh bank Syariah Mega Indonesia dengan rasio CAR sebesar 21,26\%. Disini terlihat bahwa bank Mandiri Syariah (pada tahun 2001 sampai dengan tahun 2003) dan bank Syariah Mega Indonesia (pada tahun 2004) belum optimal dalam menggunakan modalnya, serta masih belum begitu berani untuk menyalurkan dananya pada aktiva-aktiva yang beresiko.

Rata-rata debt equity industri perbankan syariah mulai tahun 2001 sampai dengan tahun 2002 mengalami peningkatan. Hal ini menunjukkan bahwa jumlah hutang dari tahun ke tahun semakin besar. Debt to equity perbankan syariah di Indonesia dari tahun ke tahun terus mengalami peningkatan yang cukup besar. Hal ini mengindikasikan bahwa perbankan Syariah di Indonesia mulai tahun 2001 sampai dengan tahun 2004 tidak dapat menutupi hutang-hutangnya dengan modal sendiri yang dimilikinya, karena kemampuan debt to equity lebih besar dari $100 \%$. Perkembangan long term debt to equity ratio bank mandiri Syariah pada tahun 2001 sebesar $29,86 \%$. Hal ini menunjukkan bahwa $29,86 \%$ dari aktiva yang dimiliki oleh bank berasal dari hutang jangka panjang. Nilai long term debt to equity bank Mandiri syariah pada tahun 2002,2003, 2004 terus mengalami peningkatan. Hal ini berarti bahwa dari tahun ke tahun semakin besar jumlah aktiva yang dibiayai oleh hutang jangka panjang.

Hal ini patut diwaspadai oleh pihak bank untuk semakin berhati-hati untuk memilih aktiva mana saja yang akan dibiayai oleh hutang jangka panjang, sehingga hasil yang diterima sebanding dengan beban bunga yang harus dibayar. Sedangkan long term debt to equity bank Muamalat Indonesia mulai tahun 2001 sampai dengan tahun 2002 terus mengalami penurunan. Hal ini mengindikasikan bahwa pihak bank berusaha untuk mengurangi proporsi hutang jangka panjangnya, yang pada tahun 2001 sebesar 70,55\% dan diakhir tahun 2004 sebesar 43,45\%.

Komposisi hutang jangka panjang terkecil pada tahun 2001 dan tahun 2002 diraih oleh bank Mandiri Syariah, yaitu 29,86\% pada tahun 2001 dan 42,61 pada tahun 2002. Sedangkan pada tahun 2003 dan tahun 2004 long term debt to equity terkecil dicapai oleh bank Muamalat Indonesia dengan nilai 53,58\% pada tahun 2003 dan 43,45\% pada tahun 2004. 


\section{KESIMPULAN}

1. Kemampuan CAR mulai tahun 2001 sampai dengan tahun 2004 nilainya melebihi standar yang telah ditetapkan oleh BI. Besarnya CAR yang jauh diatas standar menunjukkan bahwa bank belum menggunakan modalnya secara optimal. Hal mungkin dikarenakan oleh adanya keraguan bank untuk menyalurkan dananya pada aktiva yang beresiko

2. Debt to equity mulai tahun 2001 sampai dengan 2004 terus mengalami peningkatan . hal ini menunjukkan bahwa jumlah hutang dari tahun ke tahun terus meningkat.

3. Long term debt to equity mulai tahun 2001 sampai dengan tahun 2003 yang nilainya paling kecil pada industri perbankan syariah adalah bank Mandiri Syariah. Sedangkan tahun 2004 adalah bank Muamalat Indonesia. Hal ini berarti bahwa bank Mandiri Syariah dan bank Muamalat merupakan bank yang komposisi hutang jangka panjangnya dibawah rata-rata industri, sehingga semakin kecil long term debt to equity ratio maka semakin kecil pula aktiva bank yang dibiayai oleh hutang jangka panjang.

\section{Saran-saran}

Bank syariah merupakan salah satu lembaga keuangan yang memberikan pelayanan berdasarkan konsep syariah Islam. Dengan mayoritas masyarakat yang beragama Islam merupakan salah satu peluang bagi perbankan syariah untuk mengembangkan usahanya. Kegiatan yang sebaiknya ditingkatkan berkenaan dengan pengembangan perbankan syariah adalah dengan sosialisasi, edukasi dan promosi dan bekerja sama dengan lembaga terkait untuk meningkatkan preferensi masyarakat terhadap perbankan syariah Dari sinilah maka bank syariah dapat lebih mengoptimalakan penarikan dana dan menyalurkannya kembali dana tersebut ke masyarakat.

Sejak dikeluarkannya fatwa Dewan Syariah Nasional tentang Obligasi Syariah pada September 2002 merupakan suatu alternative pembiayaan bagi kegiatan operasional perbankan syariah. Penerbitan obligasi syariah secara efektif dapat memperkuat struktur permodalan mengingat obligasi syariah merupakan salah satu bentuk pembiayaan jangka panjang. Untuk penelitian berikutnya diharapkan juga akan menggali, mengsinergikan, 
serta mengkaji data primer serta data sekunder dari perbankan syariah sehingga hasil yang dicapai akan lebih mendalam dan lengkap.

\section{DAFTAR PUSTAKA}

Abdullah M. Faisal,. Drs, MM. 2003. Manajemen Perbankan (Teknik Analisis Kinerja Keuangan Bank). Malang: UMM Press.

Antonio, Muhammad Syafi'i. 2001. Bank Syariah : Dari Teori Ke Praktik. Jakarta: Gema Insani Press.

Arifin, Zainul Drs. MBA. 2002. Dasar-dasar Manajemen Bank Syariah. Jakarta Alfabet.

BI 2001. Direktori Perbankan Indonesia 2001. Jakarta : Bank Indonesia

BI 2002. Direktori Perbankan Indonesia 2002. Jakarta : Bank Indonesia

BI 2003. Direktori Perbankan Indonesia 2003. Jakarta : Bank Indonesia

BI 2004. Direktori Perbankan Indonesia 2004. Jakarta : Bank Indonesia

BI 2005. Direktori Perbankan Indonesia 2005. Jakarta : Bank Indonesia

Dandawijaya, Lukman Ir. Drs. 2003. Manajemen Perbankan. Jakarta: Ghalia Indonesia

Hasan, M. Iqbal, Ir. Drs. 2003. Pokok-pokok Materi Metodologi Penelitian dan Aplikasinya. Jakarta: Ghalia Indonesia.

IAI. 2002. Kerangka Dasar Penyusunan dan Penyajian Laporan Keuangan Bank Syariah. Jakarta: Salemba Empat.

Kuswandi, Daniel S. SE, AK, MBA, dkk. 1997. Akuntasi Perbankan (Akumulasi Bank Dalam Valuta Rupiah). Jilid I. Jakarta: Institut Bankir Indonesia.

Muhammad. 2001. Sistem dan Prosedur Operasional Bank Syariah. Yogyakarta: UII press

-----, 2001. Teknik Perhitungan Bagi Hasil di di Bank Syariah. Yogyakarta: UII Press

Santoso, Ruddy Tri. 1995. Prinsip Dasar Akuntasi Perbankan. Yogyakarta: Andi Offset

Sumarso, SR. 1992. Akuntasi : Suatu Pengantar Jilid I. Jakarta: Rineka Cipta.

Surat Edaran Bank Indonesia Nomor 2/5 BPPP Tanggal 29 Mei 1993 Tentang Tata Cara Penilaian Tingkat Kesehatan Bank.

Surat Keputusan Direksi Bank Indonesia Nomor: 30/11/KEP/DIR Tanggal 30 April 1997.

Syamsudi, MA.Drs. Lukman.1998. Manajemen Keuangan Perusahaan. Jakarta: PT. Raja Grafindo Persada. 
Surat Keputusan Direksi Bank Indonesia Nomor 30/227/KEP/DIR Tanggal 19 Maret 1998 Surat Keputusan Direksi Bank Indonesia Nomor 31/148/KEP/DIR Tanggal 12 November 1998.

Undang-undang Nomor 7 Tahun 1992.

Undang-undang Nomor 10 Tahun 1998

www. BI. Co. id

${ }^{*)}$ Indah Yuliana, SE., MM., Dosen Fakultas Ekonomi UIN Malang 